\title{
Directly estimating the private healthcare services demand in Romania
}

\author{
Dumitrescu Luigi \\ "Lucian Blaga" University of Sibiu \\ Romania \\ e-mail:dumitresculuigi@yahoo.com

\section{Cetină Iuliana} \\ The Bucharest University of Economic Studies \\ Romania \\ e-mail: cetina.iuliana@gmail.com
}

\section{Pentescu Alma}

The Bucharest University of Economic Studies

Romania

e-mail:alma_pentescu@yahoo.com

Yuriy Bilan

Szczecin University, Poland

e-mail:yuriy_bilan@yahoo.co.uk

Abstract. This paper aims two major objectives: (1) to bring forth and stress the importance of the market research's role in efficient and effective decision making for the private (for-profit) healthcare providers; (2) to present the importance and methodology of studying the private healthcare services demand. This latter aspect is highlighted by market studies through direct research of the consumer's perception on these services. Also, this paper aims to answer the question "how can a successful business be built on a more and more competitive market, and a market settled by more regulations than many other markets?" This is an essential question for all the managers who develop

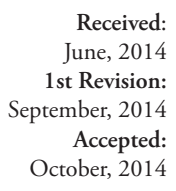

Received: June, 2014 1st Revision: September, 2014 Accepted: October, 2014 or wish to develop activities on the Romanian healthcare market.

Keywords: marketing view, market research, demand research, direct selective marketing research

\section{JEL classification: M31}

\section{INTRODUCTION}

In Romania, the government represents the highest authority within the Romanian health system, performing its stewardship role through the Ministry of Public Health. The National Health Insurance Fund 
(NHIF) represents the main financial source as the third party payer of the system and receives the funds collected by the agencies of the Ministry of Finance. Through the Yearly Framework Contract, agreed by the NHIF with the Ministry of Public Health and the CoPh, the health care services to be contracted by the District Health Insurance Funds (DHIFs) from both public and private health care providers (hospitals, ambulatory care, primary care and so on) are established (Vlădescu, Scîntee, Olsavszky, Allin, Mladovsky, 2008, p.21).

Also, the majority of health care providers are no longer public servants and state employed; rather they are paid through different contractual arrangements by the DHIFs. Primary care physicians, known as "family doctors", have been assigned the new role of private practitioner and are paid by a mix of capitation and fee for service. As regards the specialist care from ambulatory facilities, the former polyclinics have been turned into independent medical facilities and the physicians working in ambulatory care are paid by fee for service. Most hospitals are (still) under public ownership, with few initiatives of private practice. They receive prospective payments consisting of a mix of payment methods (Vlădescu, Scîntee, Olsavszky, Allin, Mladovsky, 2008, p.31).

For any private (for-profit) provider of healthcare services, increasing its market activity is the most important financial motivation. At the same time, the growth itself should not become a target. Its objective should be a profitable growth (Kotler, 2003, pp.27-28). In order to achieve this objective, the Romanian private (for-profit) healthcare providers are increasingly aware of the importance of adopting the marketing view within their activity. According to this approach, conducting market research and identifying consumers' needs is the premise of modern marketing.

From the marketing point of view, providing private healthcare services in Romania is inseparably linked to the market's economic sphere of these services, its nature, dimensions and mechanism (Balaure, 2002, pp.91-106).

The Romanian healthcare market is the field of many heterogeneous providers, both public and private (for-profit), each of them aiming to achieve a position which will ensure efficient service delivery. From this perspective, market research should provide all the information needed by managers of private (for-profit) healthcare organizations to support the marketing decision making process, in general, as well as the product, price, distribution and promotion policies.

From the marketing point of view, the starting point of any business is represented by the market and the consumers (Baker, 1994, p.4). Denner (1971) believes that marketing includes an ongoing analysis of the demand, on the one hand and, on the other hand, establishing and applying the means to satisfy it, in terms of an optimal profit. Ries and Trout (1997) are more trenchant saying that only those organizations that are committed to engage in a war, in order to win an essential award: the hearts and minds of consumers, will achieve victory.

Furthermore, from the marketing point of view, the Romanian private (for-profit) healthcare providers do not just sell products or services. They are concerned to satisfy the needs for which they were designed as fully and as efficiently as possible, so they need to gain information about the consumption behaviour. Also they need to know how well those services do satisfy the patients' needs.

\section{MARKET RESEARCH - PREMISE IN ADOPTING THE MARKETING VIEW IN PRO- VIDING HEALTHCARE SERVICES}

For the Romanian private (for-profit) healthcare providers, market research requires obtaining information about the actual or potential markets, consumer needs, their motivation, and consumer (patient) behaviour.

Adopting the marketing view in providing healthcare services starts with the content attributed to this market by the economic theory, which is developed as a practical approach. This requires the integration of 
new elements to the general market sense, such as the healthcare service provider market as an independent bidder. By itself or combined with the offer of other providers, the healthcare services offer will be confronted with the patients' demand. At the same time, defined by the consumption of healthcare services, as well as the present and future possibilities of providing these services, the healthcare market becomes a subset of the total market.

Considered by experts as one of the main components of marketing research, market research is the first stage of the marketing management process. The next stages are: market segmentation, target and positioning; the marketing mix; implementation and control (Kotler, 2003, p.40).

Researching the market is the starting point in the adoption of the marketing view in providing healthcare services Without this step, a private (for-profit) healthcare services provider acts on this market as if it were blindfolded (Dumitrescu, Apostu, 2009, p.248).

Market research will help private (for-profit) healthcare providers recognize that customers (patients) have different needs, perceptions and preferences.

For that purpose, market research is addressing both qualitative and quantitative issues. Some qualitative issues are: a) the knowledge of existing patterns of consumption or use; b) healthcare services consumer' reaction to various stimuli related to the service itself, its price, accessibility, etc.; c) consumer perception on the level of satisfaction resulted from the healthcare services; d) the knowledge of the importance attributed, by healthcare services consumers, to the price variable; e) the knowledge of consumer attitudes towards various sources of information on healthcare services, etc. As regards the quantitative issues that can be studied, some of these are: a) consumer awareness of various healthcare brands; b) purchase of different brands; c) evaluation of some attributes of healthcare products/services; d) testing the acceptability of different price levels; e) the knowledge of consumer expectations on the price of healthcare products/services; f) evaluating the importance of different sources of information.

In market research, analysis and forecasts of the Romanian healthcare market development are really important and aim the following: a) general aspects of the market; b) specific aspects of supply/ demand; c) correlating supply and demand through exchange.

Wide and complex, the market research is not conceivable without solid data on the processes and mechanisms of the Romanian healthcare market.

\section{STUDY OF THE HEALTHCARE SERVICES DEMAND}

The demand for healthcare services is the expression of current, pressing, spontaneous, and difficult to postpone needs, so that their occurrence determines, immediately or as soon as possible, the demand (Olteanu, 2008, p.126).

Avedis Donabedian (1973) defined need as that state of the individual that makes him/her require care, turning him/her into a potential healthcare services user. However, in addition to interpreting the healthcare services need in clinical terms, the patient's perception/attitude towards his/her own health, disease impact on the individual and society, the degree of dysfunction and disability caused by disease and the disease's social origins should also be taken into consideration (Drăgoi, 2010, p.77).

Tulchinsky and Varavikova (2009, pp.409-410) have an interesting point of view, considering that the need and demand for healthcare services are not necessarily the same. Need also refers to preventive care, while the demand for healthcare services occurs when the individual considers that he or she needs those services and is willing to spend money, time, energy, to travel, and to stand a number of inconveniences to receive care. The healthcare services demand is influenced by multiple factors (fig. 1). 


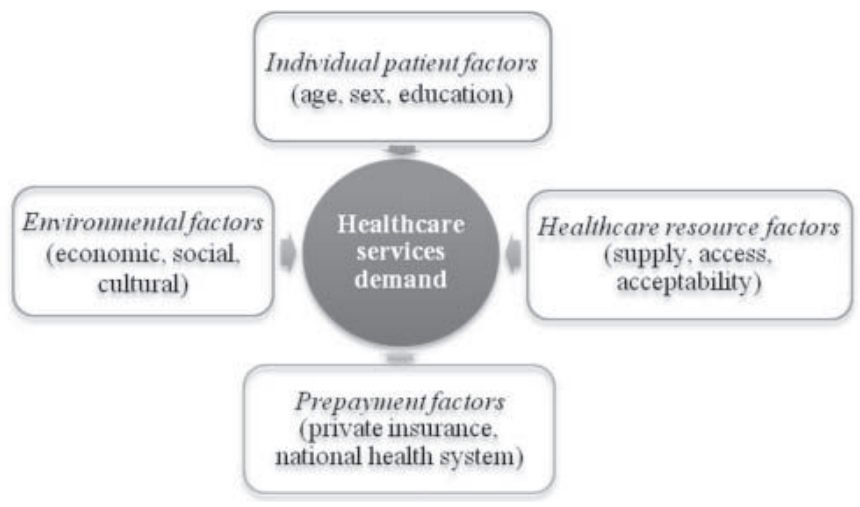

Figure 1: Factors influencing healthcare services demand

Source: adapted from Tulchinsky, Varavikova (2009), The New Public Health, $2^{\text {nd }}$ ed., Elsevier Academic Press, p.410

Within the private healthcare services sector in Romania, the core element of the market investigations is the healthcare services demand. Knowing the current and the potential customers' demand for the offered healthcare products/services is the premise for becoming patient-oriented. Studying the population's healthcare services demand involves using a variety of methods of investigation, general or specific, direct or indirect, continuous or discontinuous, fieldwork or desk research. The analytical methods use statistics to study the demand, suggesting the size and structure of the past demand for private healthcare services. If they are properly processed and interpreted, statistics can highlight the dimensions, direction and dynamics of the healthcare services demand. The indirect estimation methods address the private healthcare services demand as a result of other economic, demographic, etc. phenomena, on which information is available. The dimensions of the private healthcare services demand may be related to other factors such as the price dynamics of these services, wage dynamics, unemployment rate, inflation rate, etc. The direct methods of studying the private healthcare services demand are based on collecting information directly from the carriers of the demand, the consumers of these services.

\section{RESEARCH METHODOLOGY}

To study the demand for private healthcare services we have conducted a direct, selective marketing research between the $15^{\text {th }}$ of July and the $15^{\text {th }}$ of October 2013. The purpose of the research was to provide insights into and an understanding of consumers' perception on the healthcare services performed by the private healthcare providers from Sibiu.

In accordance with the purpose of this research, we have set the following objectives and hypotheses (tab. 1).

The respondents were consumers of healthcare services performed by the private (for-profit) healthcare providers from Sibiu (Astra, Diamed, Medica, Misan Med, Paltinul, Polisano and Sanostar). The unit of observation coincided with the unit of analysis.

The information sources used were primary, external, and cross-sectional. Thus, the information was collected directly from respondents, using a questionnaire with 19 questions. The variables were measured using nominal, ordinal and interval scales. 
Research objectives and hypotheses

\begin{tabular}{|c|c|c|}
\hline & Objectives & Hypotheses \\
\hline 1. & $\begin{array}{l}\text { Knowledge of the degree to which the healthcare } \\
\text { services consumers from Sibiu are insured by the } \\
\text { National House of Health Insurance. }\end{array}$ & $\begin{array}{l}\text { Most healthcare services consumers from Sibiu are insured } \\
\text { by the National House of Health Insurance. }\end{array}$ \\
\hline 2. & $\begin{array}{l}\text { Knowledge of the purchase behaviour of the } \\
\text { healthcare services consumers from Sibiu. }\end{array}$ & $\begin{array}{l}\text { Most healthcare services consumers from Sibiu are provided } \\
\text { with healthcare services every several months. } \\
\text { Most healthcare services that consumers from Sibiu ben- } \\
\text { efited from were paid. }\end{array}$ \\
\hline 3. & $\begin{array}{l}\text { Evaluation of consumers' awareness and knowl- } \\
\text { edge of the main private (for-profit) healthcare } \\
\text { providers from Sibiu. }\end{array}$ & $\begin{array}{l}\text { Most consumers know the main private (for-profit) health- } \\
\text { care providers from Sibiu. }\end{array}$ \\
\hline 4. & $\begin{array}{l}\text { Knowledge of healthcare services consumers' } \\
\text { perception on the main private (for-profit) health- } \\
\text { care providers from Sibiu. }\end{array}$ & $\begin{array}{l}\text { Most consumers have a favourable perception on the main } \\
\text { private (for-profit) healthcare providers from Sibiu. }\end{array}$ \\
\hline 5. & $\begin{array}{l}\text { Determining the influence of the healthcare } \\
\text { services rates' level in choosing a particular } \\
\text { healthcare provider. }\end{array}$ & $\begin{array}{l}\text { Most consumers choose the healthcare provider with the best } \\
\text { price-quality ratio. } \\
\text { For most consumers, the charged rates and all actions related } \\
\text { to them are important in choosing a healthcare provider. } \\
\text { When purchasing a healthcare service, most consumers com- } \\
\text { pare the current rate (of that service) with the rates charged } \\
\text { by other providers. }\end{array}$ \\
\hline 6. & $\begin{array}{l}\text { Knowledge of the consumers' perception on the } \\
\text { rates level and the price-quality ratio of the ser- } \\
\text { vices performed by the main private (for-profit) } \\
\text { healthcare providers from Sibiu. }\end{array}$ & $\begin{array}{l}\text { More than half of the consumers perceive the rates charged } \\
\text { by the preferred private (for-profit) healthcare provider from } \\
\text { Sibiu as high. } \\
\text { Regarding the price-quality ratio, about half of the consum- } \\
\text { ers think that the price is high compared to the quality of } \\
\text { services. }\end{array}$ \\
\hline 7. & $\begin{array}{l}\text { Knowledge of the consumers' perception on the } \\
\text { external factors that determine the private (for- } \\
\text { profit) healthcare providers from Sibiu to increase } \\
\text { their rates. }\end{array}$ & $\begin{array}{l}\text { Most consumers think that the competitors' rates are the } \\
\text { main external element responsible for increasing the health- } \\
\text { care services' rates. }\end{array}$ \\
\hline 8. & $\begin{array}{l}\text { Knowledge of the consumers' perception on the } \\
\text { internal factors that determine the private (for- } \\
\text { profit) healthcare providers from Sibiu to increase } \\
\text { their rates. }\end{array}$ & $\begin{array}{l}\text { Most consumers think that the fact the provider wants to } \\
\text { earn higher profits is the main internal reason responsible for } \\
\text { increasing healthcare services' rates. }\end{array}$ \\
\hline 9. & $\begin{array}{l}\text { Determining the main consequences of increas- } \\
\text { ing the rates charged by the private (for-profit) } \\
\text { healthcare providers from Sibiu on the consum- } \\
\text { ers' behaviour. }\end{array}$ & $\begin{array}{l}\text { Due to the higher rates charged by the private (for-profit) } \\
\text { healthcare providers from Sibiu about half of the consumers } \\
\text { have relied on self-medication instead of being examined by } \\
\text { a physician. }\end{array}$ \\
\hline 10. & $\begin{array}{l}\text { The secondary objectives will be studied ac- } \\
\text { cording to the socio-economic and demographic } \\
\text { variables of the research, namely: age, education, } \\
\text { gender, residence and income. }\end{array}$ & $\begin{array}{l}\text { Income is the main socio-economic and demographic crite- } \\
\text { rion that influences consumers' perception on the healthcare } \\
\text { services performed by the private (for-profit) healthcare } \\
\text { providers from Sibiu. }\end{array}$ \\
\hline
\end{tabular}

The conducted research was a descriptive one, which aimed to describe the characteristics of the phenomenon being studied, as it existed at the time of the study. The quantitative research was carried out through a survey, the questionnaires being distributed within private healthcare facilities. As regards the sampling technique, we used the simple, random sampling (Cătoiu, 2009). 
The sample was comprised of 440 respondents. 37 questionnaires were excluded because of inconsistent data or because of incomplete answers, leaving a finale sample of 403 respondents.

For the information's preparation and processing we used IBM SPSS Statistics (version 19) and Microsoft Office Excel (version 2007) for the charts.

\section{RESULTS}

The results of the research are: of 403 respondents, 377 (93.5\%) are insured by the National House of Health Insurance, while 26 (6.5\%) are not insured by this institution (objective no. 1). Thus, the hypothesis (most healthcare services consumers from Sibiu are insured by the National House of Health Insurance) is confirmed.

In order to gain knowledge of the purchase behaviour of the healthcare services consumers from Sibiu (objective no. 2) we have formulated the questions number two and three within the questionnaire. Analysis revealed that more than half of the respondents $(51.4 \%)$ are occasionally provided with healthcare services (fig. 2).

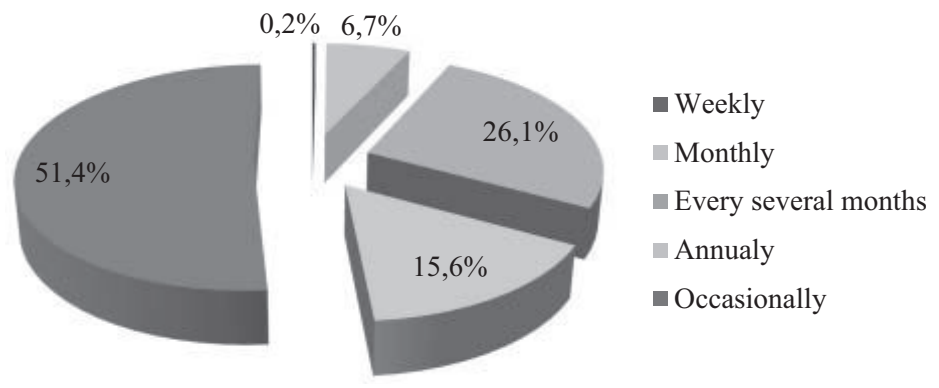

Figure 2: Frequency of healthcare services use

Source: own research.

The assumption that most healthcare services consumers from Sibiu are provided with healthcare services every several months is was not supported by the data.

As for the rates of the received healthcare services, of 403 respondents, 65.3\% (263 respondents) used mixed services (partially reimbursed by the National House of Health Insurance, the price difference being covered by the patient), while $37.4 \%$ (140 respondents) paid themselves the rates of those services.

To determine the customers' awareness and knowledge of the main private (for-profit) healthcare providers from Sibiu (objective no. 3) we have formulated the question number four, using the familiarity scale (Kotler, Keller, 2008). Since more than half of the respondents (52.1\%) chose the answer "I know a little bit about these providers" (fig. 3) it can be said that they are familiar with the main private (for-profit) healthcare providers from the city. Thus, the hypothesis according to which most consumers know the main private (for-profit) healthcare providers from Sibiu is confirmed. 


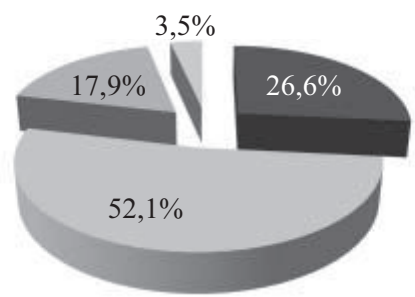

I just heard of these
providers
I know something about
these providers
I know quite a lot about
these providers
I know very well these
providers

Figure 3: Awareness and knowledge of the main private (for-profit) healthcare providers from Sibiu Source: own research.

For the following question, we used the favourable (positive) attitude scale (Kotler, Keller, 2008). As it can be seen in the figure below, of the 403 surveyed people, 54.6\% (220 respondents) perceive favourably the main private (for-profit) healthcare providers from Sibiu (objective no. 4). The hypothesis (most consumers have a favourable perception on the main private (for-profit) healthcare providers from Sibiu) is confirmed.

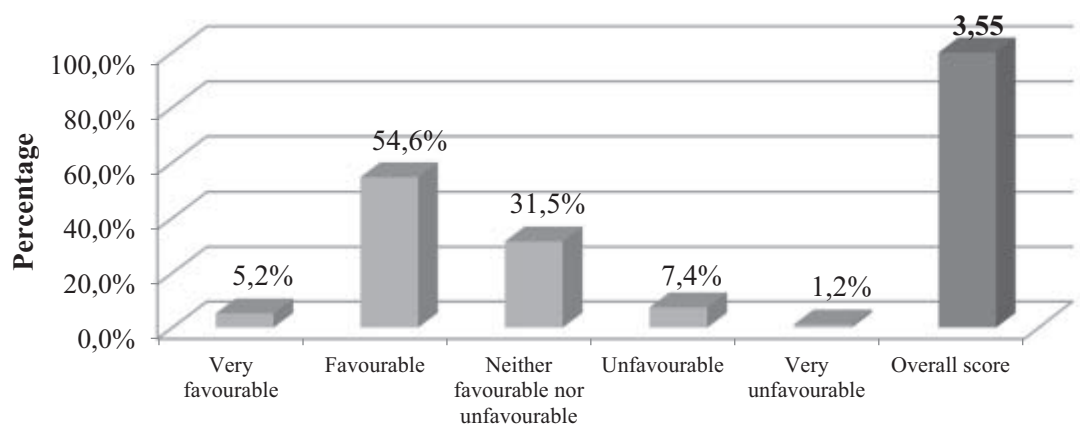

Figure 4: Respondents' perception on the private (for-profit) healthcare providers from Sibiu Source: own research.

In order to determine the influence of the healthcare services rates' level in choosing a particular healthcare provider (objective no. 5) we have formulated the questions number six, seven and eleven within the questionnaire. Data analysis revealed that $37.5 \%$ of consumers are influenced only to some extent in choosing the provider with the lowest rate, and $25.3 \%$ to a small extent (fig. 5). This fact was confirmed by calculating the overall score $(=2.67$, which means that consumers' decision is little influenced by charging the lowest rate).

However, most of the consumers (74.2\%) seek the best price-quality ratio when choosing a particular private (for-profit) healthcare provider (fig. 6). 


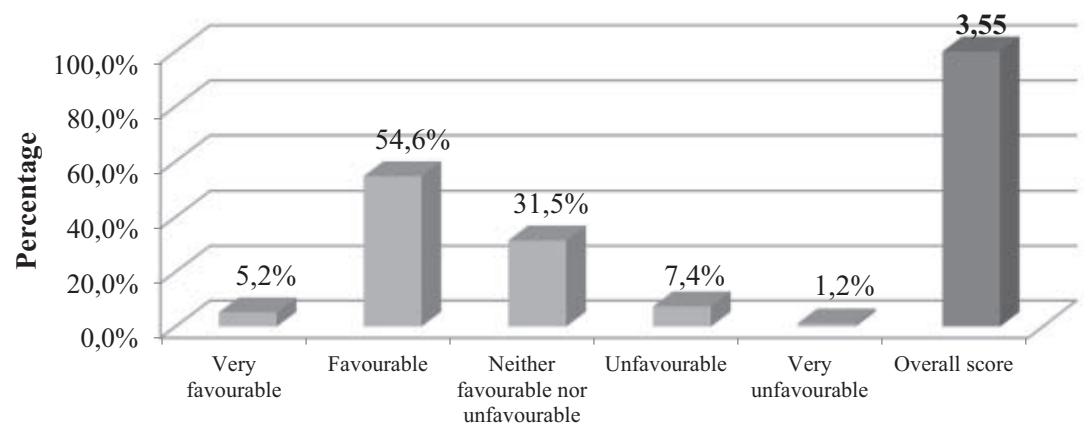

Figure 5: Respondents' choice of the provider with the lowest rate

Source: own research.

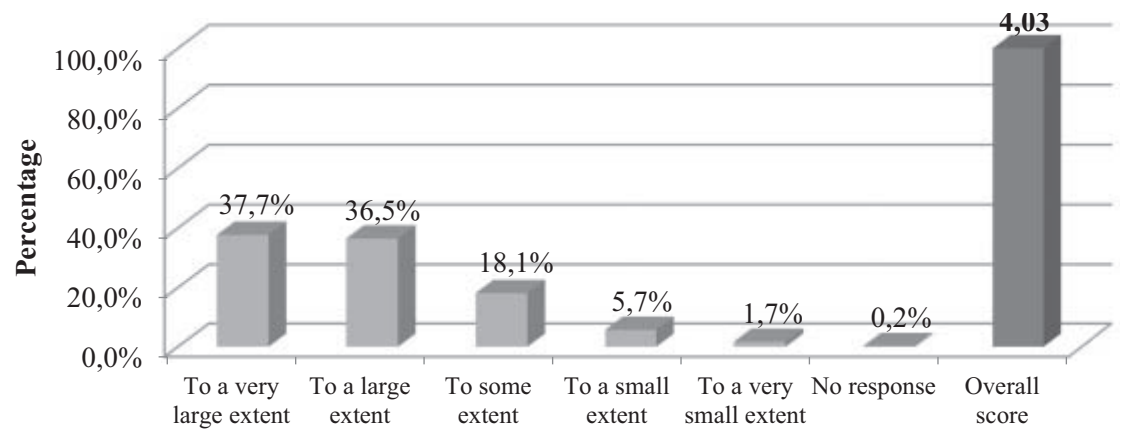

Figure 6: Respondents' choice of the provider with the best price-quality ratio Source: own research.

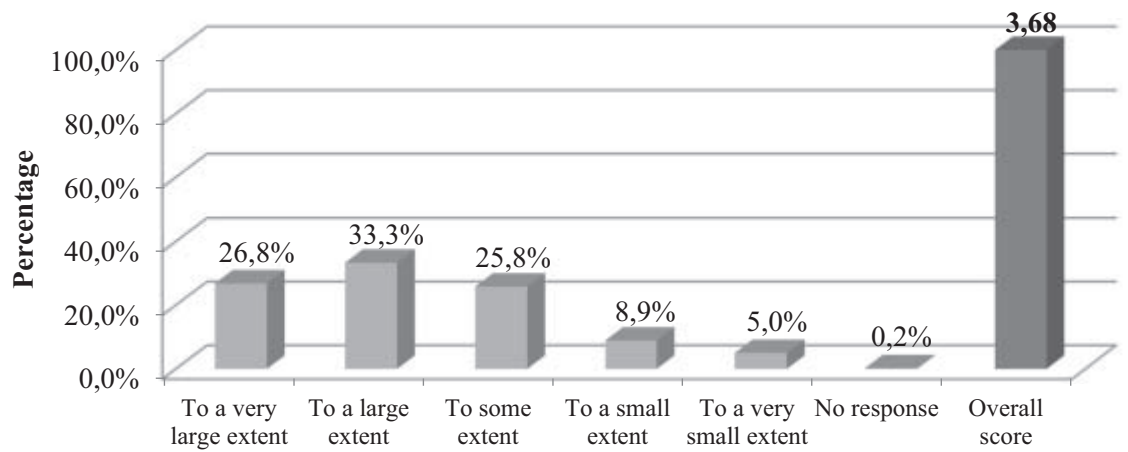

Figure 7: Respondents' choice of the provider which performs high quality healthcare services, regardless of its rates Source: own research. 
The low importance attributed to the healthcare services' rates level can be observed in figure 7. Thus, $60.1 \%$ of the surveyed people say that they choose the provider which performs high quality healthcare services, regardless of its rates.

The overall score analysis of these options shows that most consumers are primarily interested in getting the best price-quality ratio (with an overall score of 4.03) when choosing a particular healthcare provider. Also, there is a relatively high interest in choosing the provider which performs high quality healthcare services, regardless of its rates (with an overall score of 3.68). Providing healthcare services at the lowest rate seems to have the least influence on consumers' choice of a particular provider (with an overalls score of 2.67). Thus, in healthcare, the charged rates do not have the greatest influence on the purchase decision, but other attributes (for example the service quality) seem to have a greater impact on the customers' decision. The assumption that most consumers choose the healthcare provider with the best price-quality ratio is confirmed.

The results obtained for the question number seven confirm the fact that the rate of healthcare services is not the most important deciding factor in choosing a provider, with an overall score of 3.50 . However, if it is not compared with other attributes, the charged rates and all actions related to them (for example using promotional pricing) are important for most of the respondents, as illustrated by the chart below.

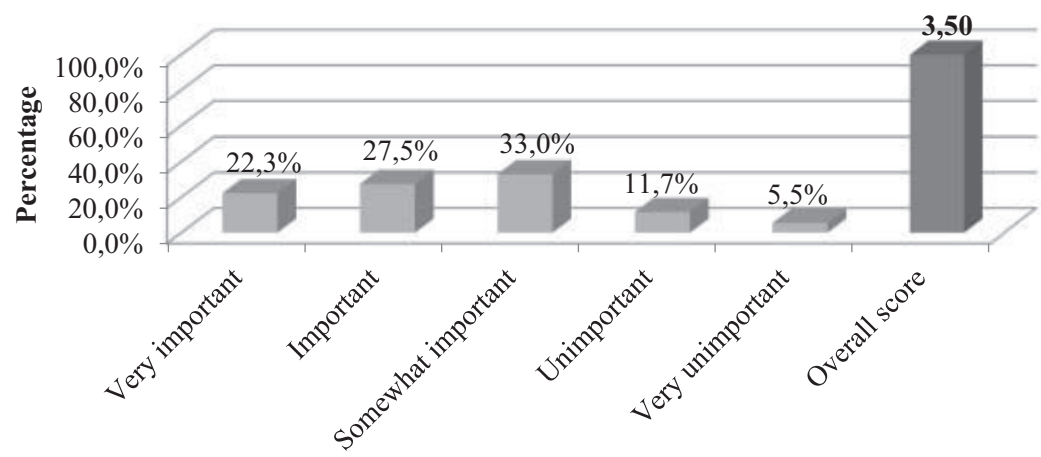

Figure 8: Respondents' opinion on the importance of the charged rates in choosing a healthcare provider Source: own research.

The hypothesis according to which for most of the consumers, the charged rates and all actions related to them are important in choosing a healthcare provider is confirmed.

Asked to what they compare the current rate of the provided healthcare service, most of the consumers said that they compare it with the rates charged by other providers (fig. 9). Thus, the hypothesis (when purchasing a healthcare service, most consumers compare the current rate (of that service) with the rates charged by other providers) is confirmed. 


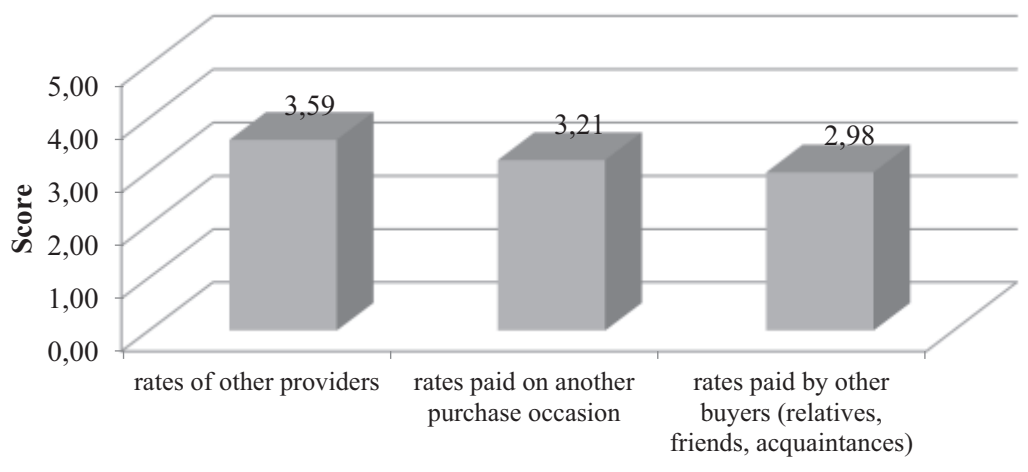

Figure 9: The hierarchy of the criteria used to compare the rate of the healthcare services when choosing a particular private (for-profit) healthcare provider

Source: own research.

In order to gain knowledge of the consumers' perception on the rates level and the price-quality ratio of the services performed by the main private (for-profit) healthcare providers from Sibiu (objective no.G), the respondents were asked to name the preferred healthcare provider (fig. 10). Hence, of the 403 respondents, 246 (61\%) named Polisano, 67 (16.6\%) Astra, 25 (6.2\%) Medica, the other mentioned the polyclinics Paltinul (chosen by 19 respondents), Misan Med and Diamed (each of them mentioned by 18 respondents) and Sanostar (chosen by 10 respondents).
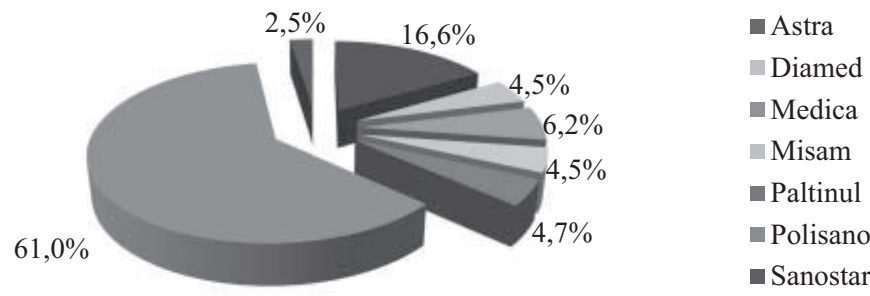

Figure 10: Respondents' preference for the main private (for-profit) healthcare providers from Sibiu Source: own research.

Next, respondents were asked to evaluate the rates charged by the above mentioned private (for-profit) healthcare provider. Thus, of the 403 surveyed people, 264 (65.5\%) said that they are reasonable, whereas $122(30.3 \%)$ said that they are high (fig. 11).

The hypothesis (more than half of the consumers perceive the rates charged by the preferred private (for-profit) healthcare provider from Sibiu as high) was not supported by the data.

As regards the price-quality ratio (fig. 12), most consumers think that the price corresponds with the quality of the provided healthcare services (with an overall score of 3.89). 


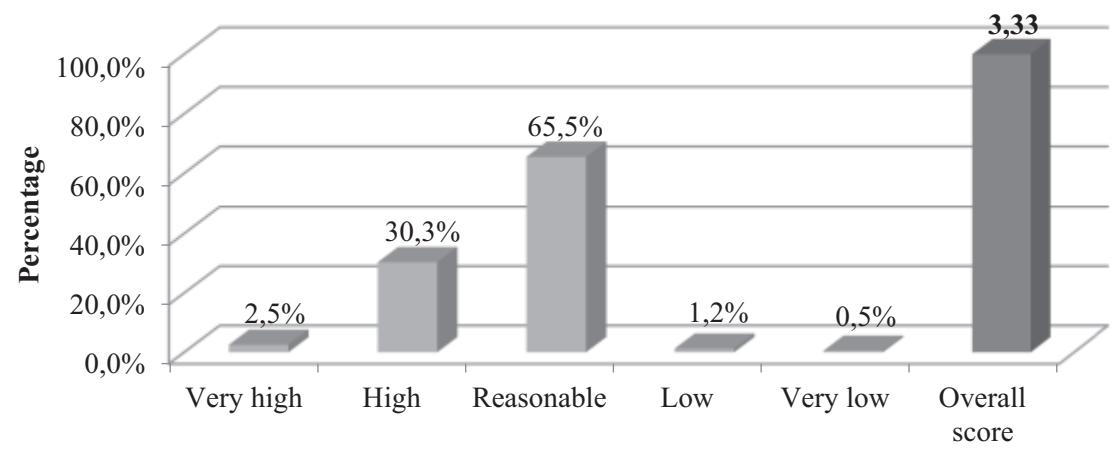

Figure 11: Respondents' opinion on the rates charged by the preferred private (for-profit) healthcare provider Source: own research.

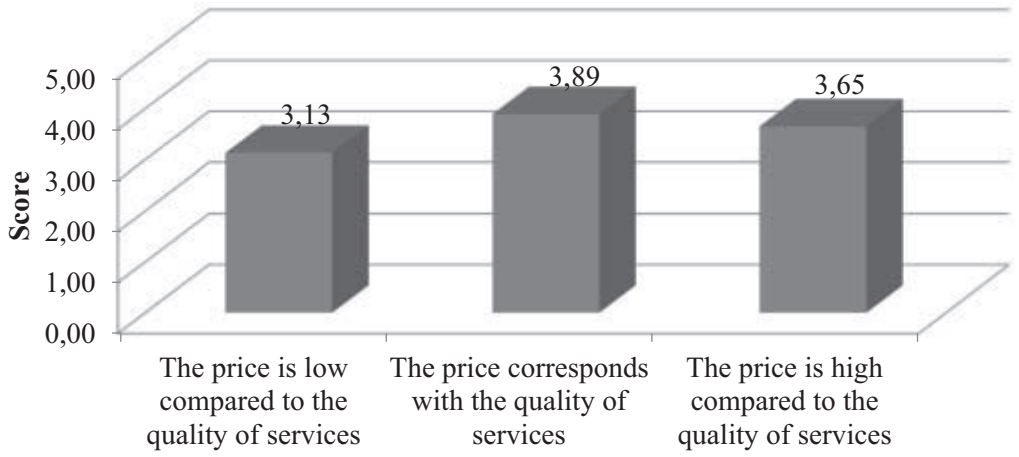

Figure 12: Respondents' opinion on the price-quality ratio of the healthcare services performed by their preferred private (for-profit) healthcare provider

Source: own research.

The assumption that, in terms of the price-quality ratio, about half of consumers think that the price is high compared to the quality of services provided by their preferred healthcare provider was not supported by the data.

To gain knowledge of the consumers' perception on the external factors that determine the private (forprofit) healthcare providers from Sibiu to increase their rates (objective no. 7) we have formulated question number twelve. Data analysis revealed that most consumers believe that this is the effect of the cost increase (with an overall score of 3.81), the inflation and the fiscal policy (both with an overall score of 3.60). From the customers' point of view, the rates charged by other competitors have the smallest influence on increasing healthcare services' rates (fig. 13). 


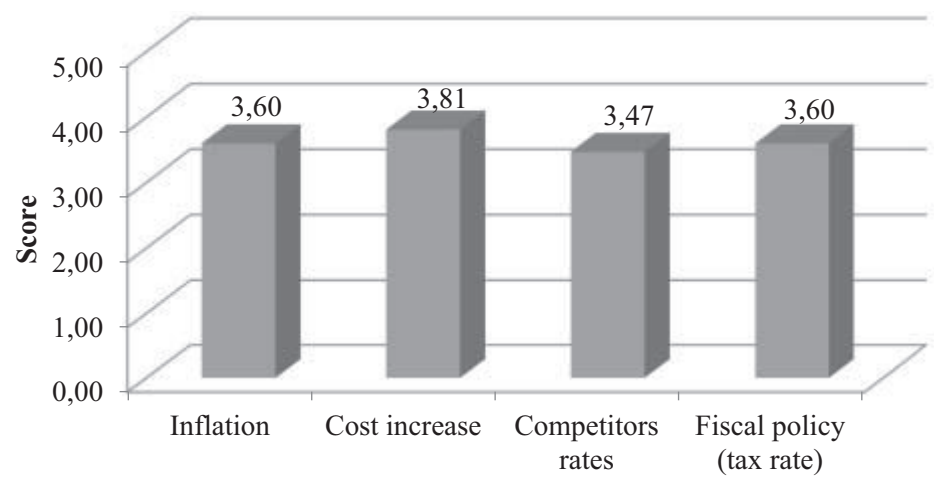

Figure 13: The hierarchy of the external factors that determine the private (for-profit) healthcare providers from Sibiu to increase their rates

Source: own research.

The hypothesis according to which most consumers think that the competitors' rates are the main external element responsible for increasing the healthcare services' rates was not supported by the data.

Furthermore, to study the consumers' perception on the internal factors that determine the private (for-profit) healthcare providers from Sibiu to increase their rates (objective no. 8) we have formulated the question number thirteen from the questionnaire. Thus, consumers think that the rates increases are due to the provider's desire to earn more profit (with an overall score of 3.67), as well as due to its reputation (with an overall score of 3.61) and as a consequence of service quality improvement (with an overall score of 3.60), as illustrated by the chart below.

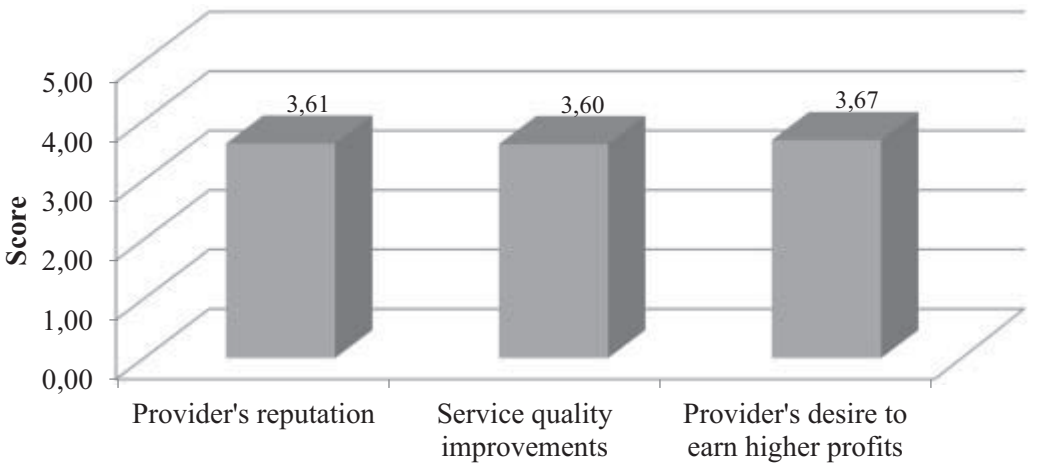

Figure 14: The hierarchy of the internal factors that determine the private (for-profit) healthcare providers from Sibiu to increase their rates

Source: own research.

The hypothesis (most consumers think that the fact the provider wants to earn higher profits is the main internal reason responsible for increasing healthcare services' rates) is confirmed. 
To determine the main consequences of increasing the rates charged by the private (for-profit) healthcare providers from Sibiu on the consumers' behaviour (objective no. 9) we have formulated the question number fourteen. Data analysis showed that increases in the healthcare services' rates do not influence the purchase behaviour of the majority of consumers (53\%). However, about a quarter of the people surveyed (24\%) said that due to an increase in the healthcare services' rates charged by the private (for-profit) healthcare providers they have relied on self-medication instead of being examined by a physician. $11 \%$ of the respondents said they gave up or postponed the necessary healthcare service, while $9 \%$ gave up dental care or a scheduled medical examination (fig. 15).

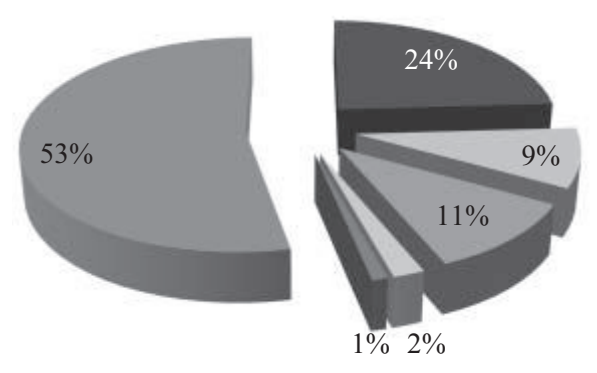

- Self-medication

Gave up dental care or scheduled medical examination

Gave up/postponed the necessary healthcare service

Didn't pick up my prescription

Halved the pill or missed some doses

None of the above mentioned

Figure 15: The consequences of the increases in the healthcare services' rates within the private sector Source: own research.

The hypothesis according to which due to the higher rates charged by the private (for-profit) healthcare providers from Sibiu about half of the consumers have relied on self-medication instead of being examined by a physician was not supported by the data.

As regards the demographics of the respondents, 30.8\% of them are aged between 18 and 25 years, $24.6 \%$ between 26 and 35 years, $25.1 \%$ between 36 and 45 years, $13.2 \%$ between 46 and 55 years, $4.5 \%$ between 56 and 65 years and $2 \%$ are more than 65 years old. In terms of their education, more than half of the respondents $(54.1 \%$ ) have a university degree, $31.3 \%$ have graduated secondary education and $14.6 \%$ have post-graduate studies. Furthermore, $60 \%$ of the respondents are female and $40 \%$ male. The distribution of respondents by residence is biased towards urban, $77.9 \%$ of the surveyed people living in urban areas. Regarding the income, $13.4 \%$ earn less than 700 lei/month, $15.1 \%$ earn between 700 and 1000 lei/month, $22.6 \%$ between 1100 and 1500 lei/month, $17.4 \%$ between 1600 and 2000 lei/month, $7.4 \%$ between 2000 and 2500 lei/month, and $7.7 \%$ earn more than 2500 lei/month. $15.9 \%$ did not respond.

To test the degree of association between variables (objective no. 10), we used the Pearson correlation coefficient (a measure of the linear correlation between two variables, where the value $r=1$ means a perfect positive correlation and the value $r=-1$ means a perfect negative correlation). After examining the dispersion diagrams there was no evidence of a curvilinear relationship or an unwanted influence of outliers. Thus, there is a positive, weak relationship between the knowledge of the main private (for-profit) healthcare providers and their perception on them $(r=0.21, \mathrm{df}=401, \mathrm{p}<0.01)$. Therefore, it seems that as consumers gain more knowledge about the private (for-profit) healthcare providers, their perception on them improves. Also, there is a positive, weak relationship between the knowledge of the main private (for-profit) healthcare 
providers and consumers' age $(r=0.20, \mathrm{df}=401, \mathrm{p}<0.01)$. Therefore, as customers are getting older they seem to know more about the private (for-profit) healthcare providers. The assumption that income is the main socio-economic and demographic criterion that influences consumers' perception on the healthcare services performed by the private (for-profit) healthcare providers from Sibiu was not supported by the data.

\section{DISCUSSION}

The conducted marketing research allowed us to reach some extremely useful conclusions for the private (for-profit) healthcare providers interested in the Romanian healthcare market.

First of all, the majority of the respondents said they know something about the private (for-profit) healthcare providers, which means that the goal of the future marketing communications of these providers should be the increase of actual and potential customers' knowledge.

Secondly, the research highlighted patients' pursuit of the best price-quality ratio of the provided healthcare services, not just their rates.

Thirdly, the research has revealed that, from the patient's point of view, the main external factors that determine healthcare providers to increase their rates are the provider's cost increase, the inflation and the fiscal policy of the state.

Fourthly, the research highlighted that although rates are perceived as high, their level does not influence significantly the consumers' purchase behaviour of private healthcare services.

Last but not least, the consumer perceptions research strengthens the marketing experts' (Cetină, 2009, p.292; Rădulescu, 2008, pp.48-49) opinion that the healthcare market is different from other markets due to uncertainty and asymmetry, price mechanism, healthcare service's heterogeneity, state's role, entry barriers and ethical issues.

\subsection{Limitations and future research}

The research was conducted in only one city: Sibiu. Thus, the research could be repeated in other areas of the country, with more private (for-profit) healthcare providers (for example: Bucharest or Cluj-Napoca).

\subsection{Managerial implications}

Given the fact that more than half of the respondents chose the answer "I know a little bit about these providers" while the familiarity scale (Kotler, Keller, 2008, p.798) starts from "I never heard of these providers" $\rightarrow$ "I heard of these providers" $\rightarrow$ "I know a little bit about these providers" $\rightarrow$ "I know a fair amount about these providers" and ends with "I know very well these providers", we believe that the majority of potential customers are not well enough informed about the main private (for-profit) providers and their services. Therefore, managers of these units should be concerned with raising awareness (among potential customers) of the services provided.

Furthermore, the research highlighted that although rates are perceived as high, their level does not influence significantly the consumers' purchase behaviour of private healthcare services. Thus, in healthcare, the charged rates do not have the greatest influence on the purchase decision, but other attributes (for example the service quality) seem to have a greater impact on the customers' decision. In this regard, Frederick Reichheld (2003) believes that customer's willingness to recommend the organization/service to a friend results from how well the customer is treated by frontline employees, which in turn is determined by all 
the functional areas that contribute to a customer's experience. Therefore, special attention should be paid to the processes of recruitment, selection, training and motivation of employees, because employees can be a competitive advantage.

\section{REFERENCES}

Baker, M., (1994). The Marketing Book, $3^{\text {rd }}$ ed., Oxford: Butterworth-Heinemann

Balaure, V. (ed) (2002). Marketing, $2^{\text {nd }}$ ed., Bucharest: Uranus Publishing House

Codourey, M., (2013). The Public Handshake, the Pushed Gossip and the Healthcare Marketing, Economics and Sociology, Vol. 6, No 2, 2013, pp. 11-27. DOI: 10.14254/2071-789X.2013/6-2/2

Cetină, I. (ed.) (2009). Marketingul serviciilor. Fundamente și domenii de specializare (Services Marketing. Fundamentals and Areas of Specialization), Bucharest: Uranus Publishing House

Denner, A., (1971). Principes et practique du marketing, Paris: Editions J. Delmas

Donabedian, A., (1973). Aspects of Medical Care Administration: Specifying Requirements for Health Care, Harvard University Press in Drăgoi, M. C., (2010), Sistemul de sănătate din România în context european (The Romanian Healthcare System in European Context), Bucharest: ASE Publishing House

Drăgoi, M. C., (2010). Sistemul de sănătate din România în context european (The Romanian Healthcare System in European Context), Bucharest: ASE Publishing House

Dumitrescu, L., Apostu, C., (2009). Marketingul și calitatea serviciilor (Marketing and Service Quality), Bucharest: Expert Publishing House

Kotler, P., (2003). Kotler despre marketing: cum să creăm, cum să câștigăm și cum să dominăm piețele (Kotler on Marketing: How to Create, Win, and Dominate Markets), Bucharest: Curier Marketing Publishing House

Kotler, P., Keller, L. K., (2008). Managementul marketingului (Marketing Management), $5^{\text {th }}$ ed., Bucharest: Teora Publishing House

Olteanu, V., (2008). Marketingul serviciilor - o abordare managerială (Services Marketing - A Managerial Approach), Bucharest: Ecomar Publishing House

Rădulescu, V., (2008). Marketingul serviciilor de sănătate (Healthcare Services Marketing), Bucharest: Uranus Publishing House

Reichheld, F., (2003), The One Number You Need to Grow, Harvard Business Review, 81(12): 47-54

Ries, A., Trout, J., (1997). Marketingul ca război (Marketing Warfare), Bucharest: Antet Publishing House

Tulchinsky, T. H., Varavikova, E. A. (2009), The New Public Health, $2^{\text {nd }}$ ed., Elsevier Academic Press

Vlădescu, C., Scîntee, G., Olsavszky, V., Allin, S., Mladovsky, P., (2008). Romania: Health System Review, Health Systems in Transition, 10(3): 1-172 